\title{
The European Sustainable Chemistry Award
}

O recém criado prémio Europeu "The European Sustainable Chemistry Award", uma iniciativa da EuCheMS,

foi atribuído ao Pro-

fessor Doutor Matthias Beller, Director do Leibniz Institute for Catalysis (LIKAT) situado em Rostock, Alemanha, pelo seu trabalho excepcional na área da catálise homogénea. O prémio, no valor de $10000 €$, foi entregue durante a Cerimónia de Abertura do $3^{\circ}$ Congresso de Química da EuCheMS, no passado dia 29 de Agosto em Nuremberga, Alemanha.

De entre as 21 nomeações avaliadas por um painel de especialistas, a escolha recaiu neste investigador, autor ou co-autor de mais de 420 artigos científicos e detentor de cerca de 90 patentes. O Prof. Dr. Matthias Beller e o seu grupo de investigação têm desenvolvido trabalho no campo da conversão de pequenas moléculas em materiais recicláveis ou reutilizáveis, de uma forma ambientalmente sustentável. O LKAT, o maior Instituto de investigação Europeu dedicado à catálise aplicada, incide o seu trabaIho na transferência de investigação fundamental para o campo das aplicações práticas. Na última década, o Prof. Dr. Matthias Beller e os seus colaboradores desenvolveram três sistemas de catálise actualmente utilizados pela indústria, os quais permitem a produção em larga escala (toneladas) de diferentes produtos químicos. A sua investigação tem incidido sobretudo nos seguintes aspectos: reacções de acoplamento de halogenetos de arilo catalisadas por paládio, catálise oxidativa enantioselectiva, aplicações catalíticas para a obtenção de princípios activos para utilização farmacêutica e carbonilações catalíticas. Vários dos seus projectos de investigação focam o desenvolvimento de reacções de oxidação catalítica com oxigénio ou peróxido de hidrogénio.

No âmbito da exploração de reacções catalíticas para a síntese de novas substâncias com aplicação farmacêutica, têm investigado de forma intensiva, e em particular, a adição regiosselectiva de aminas a ligações duplas e reacções de carbonilação. Este trabalho, desenvolvido em cooperação com empresas farmacêuticas, tem como objectivo o desenvolvimento de novos analgésicos, de fármacos antiAlzheimer e de inibidores de proteínas-cinase.
O prémio "The European Sustainable Chemistry Award", uma iniciativa da EuCheMS, com o encorajamento da Agência Europeia do Ambiente e o apoio da SusChem (Plataforma Europeia para a Química Sustentável) e do CEFIC (Associação Europeia da Indústria Química), surgiu com o intuito de aumentar a visibilidade da química sustentável e de incentivar a inovação e competitividade. O prémio destina-se a:

x reconhecer indivíduos ou pequenos grupos de investigação que contribuam de forma significativa para o desenvolvimento sustentável mediante a aplicação da química verde e sustentável;

$x$ promover inovações no campo da química que se traduzam em melhorias claras na produção e utilização sustentável de produtos químicos;

x demonstrar que a química e os produtos químicos podem desempenhar um papel central na concretização das necessidades da sociedade e, simultaneamente, minimizar e/ou resolver problemas ambientais.

(fonte: EuCheMS)

\section{OPINIÃO $7 \sqrt{2}-\frac{5}{1}$ \\ O INDICADOR}

\section{Básico}

Atribui-se ao físico Rutherford, Prémio Nobel para a Química em 1908, a seguinte frase, em resposta a quem comparava as condições de trabalho no seu laboratório com as de outros mais ricos: "Gentlemen, we haven't got the money, so we've got to think."

\section{Ácido}

O Joint Research Centre da União
Europeia abriu há pouco tempo concurso para investigadores, com o titulo "Europeneeds researchers". Uma das áreas contempladas é a Química. Entre diversos benefícios, oferecese contrato permanente, aquilo que entre nós continua a ser uma miragem para centenas de investigadores de qualidade comprovada, e que vão vivendo de sucessivas bolsas e contratos de duração fixa. O Indicador interroga-se, perplexo: mas afinal o tempo dos empregos para toda a vida não acabou, como afirmam certos senhores omniscientes que dão o exemplo, saltando - sempre com rede - de job em job ? Será isto a "Europa a duas velocidades"?

PH 